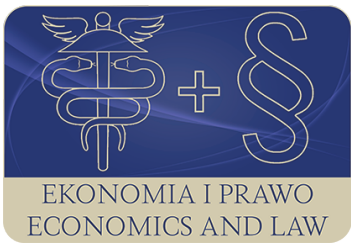

EKONOMIA I PRAWO. ECONOMICS AND LAW

Volume 18, Issue 1, March 2019

p-ISSN 1898-2255, e-ISSN 2392-1625

www.economicsandlaw.pl

ORIGINAL ARTICLE

received 02.01.2018; revised 12.06.2018; accepted 31.03.2018

Citation: Ząbkowicz, A. (2019). Pension funds in Chile: bringing the state back in. Ekonomia i Prawo.

Economics and Law, 18(1): 97-110. doi:10.12775/EiP.2019.008.

\title{
Pension funds in Chile: bringing the state back in
}

\author{
ANNA ZĄBKOWICZ \\ Jagiellonian University in Kraków, Faculty of Management and Social Communication, Institute \\ of Economics, ul. prof. S. Łojasiewicza 4, 30-348 Kraków, Poland \\ ๑anna.zabkowicz@uj.edu.pl \\ (D) orcid.org/0000-0003-1977-0884
}

\begin{abstract}
Motivation: The privatized and capitalized old-age insurance in Chile has recently witnessed reforms under President Bachelet which extended the social safety net as well as re-introduced publicly-administered programs on behalf of retirees.

Aim: The article reviews the performance of the system up to the most recent reform

in aim to understand economic and political reasons for bringing the state back in, and presents results of pension engineering in a systematic way in attempt to estimate the scope of change.

Results: Bringing the state back into Chile's pension system can be viewed as a plan to subsidize total retirement benefits in order to improve the distressing rates of replacement and, in such indirect way, to support the longevity of privately-managed pension funds.
\end{abstract}

Keywords: political economy of pension reforms; funded pensions; solidarity benefits JEL: P16; B52

\section{Introduction}

More than $80 \%$ of pension savings in Chile is invested under the rules governing since the 1981 reform, which convert pension savings into contributions to privately-managed capital funds on mandatory basis. The Chilean reform pioneered a shift in old-age security systems away from public pension schemes on the pay-as-you-go (PAYG) basis towards individual pension schemes on capital basis and found followers in the 1990s, mostly among other Latin Amer- 
ican countries and in Central and Eastern Europe ${ }^{1}$. However, nowhere was the change so embracing as in Chile. The early 2lst century saw retreat from the pension funds created on mandatory basis. Also in Chile the 2008 crisis echoed with reforms of 2008 and 2015 under the socialist president, Michelle Bachelet which extend the social safety net as well as re-introduce publicly-administered programs. The change seems to be internationally meaningful, also for Poland being one of the follower-countries.

The article poses the question whether a drive in such direction in the country of vast evidence on mandatory, funded, defined-contribution pensions means a downturn of the scheme? Recent reforms are reconstructed and analyzed in aim to evaluate the weight of the change and, consequently, to form view on sustainability of such pension system design. The research was inspired by Polish re-reform to be implemented in 2018 under which mandatory funds in a new shape constitute one of the pivotal issues².

Recent years in Chile witnessed protests involving hundreds of thousands of people throughout the country against the private pension system (so called AFP system after Adminstradoras de fondos de pensiones - pension-fund management companies) and under slogans for return to the status quo before the structural reform, initiated in 1980 which privatized publicly-administered pensions. Protests were organized by students, indigenous organizations and citizens who feel their demands are not being met. In the context of the growing street protest the Concertación leftist political alliance won the 2013 elections (with abstention rate exceeding 50\%), acquired majority in both houses of parliament and guaranteed the return of Michelle Bachelet to government. President Bachelet, in her first term already, appointed an Advisory Pension Commission (so called Marcel Commission), and 90\% of that commission's recommendations were incorporated in the law enacted in 2008. In 2014, directly after her re-election, she appointed international pension commission (so called Bravo Commission) who after 16 months of work elaborated three re-reform proposals. Bravo Commission reported: 'A high percentage of the population believe that only a complete change in the AFP system would help improve pensions $(72 \%)$ and believe that most of the responsibility for low pensions lies with the AFPs (66\%)' (Commission on the Pension System, 2015, p. 17).

\section{Methodology explained}

In the research the approach of institutionalist political economy has been applied. The leading question is for whose sake were the reforms introduced

1 The causes and circumstances of this change are not fully examined yet (Barr, 2001; Singh, 1996) and the arguments put forward by the government to justify the partial pension privatization are still subject to scientific as well as political dispute (Wehlau, 2007; Ząbkowicz, 2014, 2016).

${ }^{2}$ Both pension funds on mandatory basis introduced under 1999 reform (OFEs) and new quasi-mandatory pension plans based on automatic enrollment (PPEs) are at stake. 
and which vested interests were protected. The method relies on orderly analysis which is founded on review of the literature relevant to the subject and is carried on in order as follows. We start with an observation that Chile's pension reforms of 2008 and 2015 open space for renewed role of the state. In aim to understand both economic and political reasons for the change, performance of the system up till 2015 is reviewed. Next, basics of the change are presented in a systematic way. The question is posed whether the scope of reforms challenges the shift to the funded-pensions system (the AFP-system) made in 1981. Author uses equally a literature review as personal reflection based on ongoing research. The data is taken from research reports and up-to-date economic studies.

\section{Literature review: the alarming performance}

The open social conflict as well as manifestation of politicians' concern and intensification of experts' work embodied in the two advisory pension commissions are due to a rather alarming performance of the Chilean pension system in terms of social-security principles, as they are understood by the International Labor Organization (Mesa-Lago \& Bertranou, 2016). At the eve of the first re-reform, that is in 2007, just $61.2 \%$ of labour force contributed to the pension system which was below the 1980 rate (Mesa-Lago \& Bertranou, 2016, p. 3). Though new law of 2008 mandated the coverage of all self-employed workers, one third of the labour force still lacks contributory coverage because of evasion or lack of affiliation, with the latter referring mostly to the self-employed. The presidential Commission's report of 2015 insists on punitive measures, i.e. on increase in fines imposed on employers that retain and fail to transfer contributions and on more rapid judicial procedure for the execution of sanctions.

Meantime, the armed forces and police force schemes actually remain excluded from contributions neither they are under state supervision, except for general auditing. They provide better entitlement conditions and pensions than those in the general system, and these are $90 \%$ subsidized by the state. In mid-2016 the media informed about the abuse within this public component of the pension system which certainly mobilized the protesters. A scandal erupted after revealing that the former director of the Chilean gendarmerie was receiving a pension of about 8,000 USD per month (Vasquez, 2016). The Presidential Commission recommended the same treatment and contributions which apply to the rest of labour force, however, the privilege once granted to the military and security sectors seems to be extremely hard to extinct.

Contributory pillar has discriminated substantially against women (Mesa-Lago \& Bertranou, 2016, pp. 6-8). True, that gender inequalities are caused inter alia by circumstances exogenous to the pension system, like unequal gender position in the labor market, demographic factor (longer life expectancy for women), cultural aspects (labor division in household, for instance). Nevertheless, coverage rates for women as compared to those for men turned out 
to be dramatically lower, $42 \%$ and $61 \%$ respectively. Moreover, women's position after retirement is aggravated due to gender-differentiated mortality tables. Gender specific mortality tables, applied to pension benefits or annuities in accordance with private insurance logic, unjustifiably penalized women. In effect, the annuities of women were lower, and female replacement rates were on average not more than $38 \%$ of the rates for males. The solidarity pension distribution was developed in result of 2008 reforms in favour of women which helped to improve some indices of gender equity. Nevertheless, women continue to be substantially discriminated by the system. Recent international comparisons rank Chile 125th out of 136 countries as far as equal payment for the same work concerned. The replacement rate for women is $41 \%$ of men's, while the pension average for women is 43\% of men's. With replacement rate of 31\% in 2007-2014 Chilean females land visibly below a minimum set by the ILO and the OECD, that is below pension benefit at value of $45 \%$ of the average salary during the insured active life. In this context one of the Bravo Commission's suggestions was to implement unisex mortality tables.

Benefits paid out from the system to a bulk of pensioners were inadequate to national social minimum (Mesa-Lago \& Bertranou, 2016, pp. 7-8). Figures referring to beneficiaries of a minimum pension as well as to replacement rates are suggestive. After the 1981 reform, a minimum pension was granted to those with 20 years of contributions to previous public schemes as well as it was guaranteed to those in the private system whose individual accounts were insufficient to finance it. In 2007 the minimum pension averaged $62 \%$ of the minimum wage and projections suggested that $35 \%$ of men and $60 \%$ of women would eventually receive it. To put it differently, monthly income of about a half of pensioners would be little more than a half of the minimum salary of about 390 USD. The level of average pensions was substantially increased in result of the 2008 reform due to tax-financed pension benefits targeted to the lowest-income beneficiaries. Table 1 presents the extent of this improvement between 2007 and 2014, and the relevance of APS which is a state subsidy in fact. APS is a supplementary pension benefit added to 'self-financed pension benefit' when the latter is not adequate to basic income security. In 2015, on average, the value of APS represented nearly $80 \%$ of total old-age income. This increase has favoured lowest-income beneficiaries the most and made real contributory pension in average to increase substantially. This meant, consequently, an improvement in so called rate of replacement which is an average pension as related to the average salary during the insured active life. Despite the improvement after the first wave of re-reform, the Chilean total replacement rates, however, remained close or below the internationally-acknowledged minimum of $45 \%$ as table 1 informs.

Weak competition and high administrative costs in the core private pillar of the pension system are certainly one of the major reasons of such poor performance in terms of benefits. The private system, starting from 1981 has been managed by pension fund management companies AFPs that charge fees as 
a percentage of the taxable income for administering the old-age pension, as well as a fixed fee with regressive effects. In addition, the premium to cover disability and survivor risks was collected by the AFPs and transferred to commercial insurance companies. Total costs charged by the private system has taken a quarter of fund-contributors deposits placed in individual accounts. Table 2 informs that such cost-to-deposit relation was sustained over the whole period since 1981, also after the 2008 reform $^{3}$.

Such outcomes, which seem discouraging for pension fund affiliates, are due to weak competition. First, membership is mandatory, thus the pension fund management companies do not need to compete for savings with other financial institutions, like banks or stock exchanges; in this sense they are legally privileged. Moreover, freedom of fund affiliates to select among the AFPs was restricted. Instead of desirable market competition and making administrative costs as low as practicable, concentration of assets as well as increase in average fee followed in 1981-2008. The number of AFPs dropped from 21 to 5 from 1994 to 2008, with concentration of contributors in the three major AFPs jumping from ca $67 \%$ to more than $86 \%$ (Mesa-Lago \& Bertranou, 2016, p. 9). High fees which the AFPs charge from account holders result in profits that are much larger than in other sectors of Chile's financial services industry (Kritzer, 2008, p. 77, 79). Between 1991 and 2004, AFPs earned an average of 27\% on assets. In 2005, administrative fees represented a record 91\% of an AFP's income. This made the official supervisory institution, Social Security Administration to state in 2008: 'account holders have had lower net rates of return (and smaller pensions) in part because AFPs have charged high administrative fees' (Kritzer, 2008, p. 77).

After 2008 an average old-age fee covering the costs paid to AFPs was decreasing (table 2). In common view this outcome is associated with auction mechanism introduced under the 2008 reform under which all individuals opening an account in the pension system for the first time, mostly young individuals entering the labour market, are not allowed to choose their AFP but are allocated to this provider who offers the lowest fee. Such bidding for affiliates, who by law are to stay with the bid-winning AFP for next two years at least, may be regarded as introducing cost competition between pension fund managing companies. For instance, the winner of the 2014 auction, the AFP previously with the highest fee offered new lowest fee at level of $0.47 \%$ of pensionable salary which benefited both new individual customers and all previous individual

3 This relation which seems alarming varies dramatically according to different sources. Table 2 follows Mesa-Lago's data updated with those delivered by the Bravo Advisory Pension Commission (Comisión Asesora Presidencial sobre el Sistema de Pensiones, CAPSP). A quarter of fund-contributor's deposits stands in contrast with figure $14.6 \%$ of the contribution (in 2007) as reported by supervisory bodies to pension management companies, this is Asociacion Internacional de Organismos de Supervision de Administradoras de Fondos de Pensiones (AIOS) followed by Chile's Social Security Administration (Kritzer, 2008, p. 78). 
fund members. Thus, outcomes of the Chilean auction seem to be positive, however, 'the process may still be too young to claim hard conclusions' (Garcia-Huitron \& van Leuvensteijn, 2015, p. 197). Such a radical change in the case of one AFP must have had an impact on the average old-age fee, taking the high asset concentration in the sector under consideration. Premiums charged on behalf of insurance companies (table 2), however, seem to be hardly reducible.

In terms of social-security principles the Chilean system as seen before 2015 needed improving. It covered scarcely $65 \%$ of labour force, $20 \%$ of self-employed and it left $16 \%$ of elderly population beyond the coverage. The privileged and heavily-subsidized armed forces and police force schemes continued. Nearly $40 \%$ of women were uncovered, and the female benefits in the system were diminished due to gender-differentiated mortality tables. Nearly $70 \%$ of the pensions with a solidarity component were lower than the poverty line (Mesa-Lago \& Bertranou, 2016, pp. 15-16). On the other hand, in terms of capital, the system allowed for concentration of savings amounting close to 70\% of GDP and for managing them by new investors. AFPs invest pension savings in securities such as shares, sovereign bonds, mortgage bonds, etc., and these activities are said to have 'stimulated high growth and domestic investment' (Vasquez, 2016). According to the IMF (2016), 'over the last 30 years, the fully funded Defined Contribution formula system has raised national savings, aided the development of capital markets, and reduced fiscal risks'. Such optimism contradicts, however, with evidence which reveals dangerous level of investment concentration abroad and the slow dynamism of the domestic stock market. Recently more than $40 \%$ of assets under management of AFPs was invested abroad and only $11 \%$ in local equities (Cervera, 2014, p. 3, 5). National financial instruments and arrangements are considered to be insufficient to absorb funds with a value equivalent to $69.5 \%$ of GDP. This discussion, however, must find continuation in a separate article. Obviously, introducing and maintaining the Chilean-type pension system is not a free lunch (Garcia-Huitron \& van Leuvensteijn, 2015).

\section{Bringing the state back in? The response}

This short review provides evidence that two portions of reforms under President Bachelet improved performance of the system in terms of social security due to increased engagement of the state. The ILO Social Security Convention (No. 102) of 1952 states: 'regardless of the type of administration chosen, the state must be responsible for the good management of institutions and services to ensure the protection' (Mesa-Lago \& Bertranou, 2016, p. 11). This stand corresponds even with such an extreme case as Chile's where $98 \%$ of the insured are in the private pension system. After the 1981 reform the Chilean state supervised the remaining public scheme, and then, under the 2008 reform, both the public and the private segments (Pensions Superintendence). Moreover, it covered costs of transforming and maintaining the system, namely the operational deficit resulting from closing the public system in 1982, the recognition 
bond for previous contributions to the former public scheme, the differential cost of the minimum pension, the non-contributory pension, and the armed forces and police force pension deficit. The Chilean state is in position to fulfill its obligations associated with the pension system, as recent actuarial studies confirm, till 2030 at least (Mesa-Lago \& Bertranou, 2016, pp. 14-15). This solid fiscal space owes much to yields in sales of copper and seems to be rather extraordinary and contrasting with fiscal and pension balances in other countries which introduced the Chilean-type reforms.

Before presenting where the system has arrived at the end of the day a short characteristic of structural change initiated in 1979-1980 is required. In 1981, Chile implemented mandatory individual retirement account system, managed by private AFPs and financed on the capital basis. The previous public system financed on PAYG-basis is being phased out since new entrants to the labor force have had to join the capitalization system, starting from December 31, 1982 on. The insured who chose to switch from the public PAYG to the individual account system received a recognition bond at retirement that represents the value of their accrued rights under the old public system. The bond is to be redeemed and added to the mandatory individual account when the worker retires, becomes permanently disabled or dies. If pension from an individual account plus other source of income was below the minimum level set by the government, the guaranteed minimum pension (MPG) was paid which implies state subsidy. If a person over the age of 65 did not qualify for any type of pension (or was disabled), a means-tested benefit (PASIS) was paid out, funded from general fiscal revenues (Kritzer, 2008, pp. 69-70). In sum, the Chilean retirement system between 1981 and 2008 was comprised of two pillars, the privately-administered second pillar and the first pillar, administered by the state. The latter contained the closing PAYG system and the tax-financed military-force and police-force schemes as well as retirement income safety-net. The first pillar was practically non-contributory while the second pillar constituted of mandatory contributions under the AFPs' management.

Year of 2008 saw minor change in contributory component and more significant change in the non-contributory pillar. The modified structure of the pension system is displayed in scheme 1 .

In the second contributory pillar the rules concerning mandatory pension funds remained basically the same. This is, AFPs collect workers' contributions, credit them to workers' accounts, and invest these monies according to regulations set by the government. They also contract with insurance company to provide survivors and disability insurance to their fund members. Workers contribute on obligatory basis to one of the AFP-managed funds $10 \%$ of their salary, and in addition $1.15 \%$ contribution is required to finance disability and survivorship insurance. The AFP charges an administrative commission and a premium on own behalf and on behalf of the insurance company, which is deducted from wages as well. Employees cannot withdraw their funds until they retire, but they can choose the type of instrument they want to invest in. 
At retirement, workers can buy inflation-indexed annuities purchased from insurance companies, or pull out their accumulation as phased withdrawals from the pension funds which remain with the AFPs. Pension benefit is derived from individual pension savings (PCI) then.

Two changes in the contributory pillar are worth mentioning. First, voluntary collective savings accounts on top of the mandatory individual pension savings accounts were introduced in aim to allow workers to save beyond the compulsory wage contribution. However, eight years after the change such accounts have been reported to be still heavily under-developed (Bertranou, 2016, p. 16) ${ }^{4}$. Another change was a mechanism of auctioning the entrants to the pension system, as described before.

The major change occurred in the first non-contributory pillar with regard to its structure, and, the more so, to its dimension. The MPG which was guaranteed exclusively to contributors to the second pillar as a minimum benefit was replaced with supplementary pension benefit paid out to contributors (APS) and funded from general fiscal revenues as well. The PASIS poverty relief component was replaced with other non-contributory benefit PBS. However, the real change is to be seen in the scope. The two new arrangements benefit majority of population below certain poverty line whereas social assistance under 1981 reform was extremely modest, namely, eligible workers for a minimum benefit (MPG), according to the 2006 estimations, would have constituted only $5 \%$ of the affiliates. The second poverty relief component (PASIS) had been administered at the municipal level with quotas and queuing mechanism (Bertranou, 2016, p. 4). The state's role had been mostly subsidiary due to low coverage of this retirement-income safety net. The 2008 reform meant funding or co-funding of benefits from tax revenues being extended from a very small fraction of population to $60 \%$ of the poorest. Thus, a social protection floor was established which is regarded one of major accomplishments of the reform.

As a matter of fact, the re-reforming pensions in 2008 reinforced role of the state in many respects. Apart of transforming the modest social assistance into increased tax-financed coverage of the poorest, an attempt was made to use the state's compulsory power in aim to increase coverage through the mandatory contribution tier. Namely, it was designed to reach the segment of self-employed workers in certain tax categories and with higher contributor capacity. This measure was postponed until 2018 however. Moreover, institutional innovations such as the set-up of Social Security Administration bring back 'the idea of having a public long-lasting institutions which administered public pension benefits (i.e., PBS, APS and benefits from the pre-1980 system)' (Bertranou, 2016, p. 7).

Although the 2008 reform meant progress in terms of social security, it left numerous flaws of Chile's pension system in place, as the former section in-

4 This tax-incentivized arrangement is analogical to Polish funded voluntary pension plans (PPE and PPK) which are lately officially and intensively promoted under the governmental Morawiecki Plan. 
formed. These, and low benefits in particular, possibly added to surge of social discontent. The social conflict has been also reflected in important conceptual differences among the experts of the 2014-nominated Bravo Commission. Both the Commission hearings and meetings for citizen participation showed majority's preferences for elimination or limiting the private savings component of the pension system, and restoring a reformed system based on social security principles. On the other hand, pension management companies and conservative think tanks with support of foreign experts and international organizations highlighted the need to maintain the status quo with some reforms in the volume of financing and parametric changes (Bertranou, 2016, p. 3). Consequently, the Commission's report presented in 2015 to the President Bachelet has revealed its members divided, basically, between two global proposals 5 . In a nutshell (for more technical details see Barr \& Diamond (2016, pp. 4-9)), proposal 'A' is to keep the status quo of the current system with increases in tax financed benefits. This is to say, individual pension savings accounts with mandatory and voluntary contributions remain the core of the system; however, in the non-contributory component loosening the qualifying conditions for pensions is proposed (Garcia-Huitron \& van Leuvensteijn, 2015, p. 199). Proposal ' $\mathrm{B}$ ' introduces a social insurance component thus reducing the size of individual savings component. The Commission agreed that the increment in the contribution rate is needed and that it should reach an additional 4 p.p. which implies an increment from 10 to $14 \%$. However, while proposal 'A' proposed to use these resources mostly for individual pension savings, proposal ' $\mathrm{B}$ ' recommended allocating them to fund a new social insurance scheme.

Option ' $\mathrm{B}$ ' is presented systematically in scheme 2 . It displays a new social-insurance pillar in the contributory component and, consequently, an expanded competence of the public supervisory agency, Social Security Administration.

Rebuilding social security solidarity mechanism is a novelty in the 2015 package of reforms. Workers with wages up to the median earnings distribution contribute solely to the social security fund. Workers with wages above the median are both comprised by social insurance and by the AFP-system, and thus they become beneficiaries of social insurance benefit (PSS) and pension benefit derived from individual pension savings (PCI) as well. Thanks to this novel arrangement low-income workers are going to get a minimum of economic security guaranteed and, possibly, be not subject to excessive risk neither to complicated decision-making (portfolio investment options, choice of fund administrators, etc.) to such extent as under the current system. Only those with income above certain level would contribute to the fully-funded individual saving accounts scheme and take the full risk.

The 2008 reform reinforced the role of the state in Chile's pension system. The Bravo Commission presented its report to President Bachelet in September

5 The third proposal of coming back to the PAYG-system won only one vote which may be puzzling so far as Chile's popular voice concerned. The only vote came from the expert from Poland, Professor L. Oręziak (Stowik, 2016). 
2015, proposing either higher tax financing or structural change by introducing social insurance. Whether this package of reforms wins political acceptance to become a continuation of bringing the state back in remains an open question. In aim to consider how to take things forward, the President established a Committee of Ministers, including the Ministers of Labour, Finance, Social Development, Economy and Women. At the end of 2016 Michelle Bachelet announced her government plans to send a bill to Congress seeking to overhaul the pension system. Her administration proposed increasing workers' contribution to the pension fund, thus, sparking widespread street action (Zorilla, 2016). Most probably, the Government and the Congress will make attempts to implement some of the specific proposals but may leave decisions about the global proposals (status quo or social security) till 2017.

\section{Conclusion}

The 2008 reform meant funding or co-funding of benefits from tax revenues to be extended from a very small fraction of population to $60 \%$ of the poorest. Thus, a social protection floor was established which is regarded the major accomplishment of the reform. Although it meant progress in terms of social security, it left numerous flaws of Chile's pension system in place. The recent re-reform, at least as seen in the light of 2015 report by Bravo Commission, intends to reinforce the role of the state in Chile's pension system even more, proposing either higher tax financing or structural change by introducing social insurance.

Nevertheless, as far as now the reforms left the foundations of the system intact. Year of 2008 saw minor change in the AFP's component of the system and the rules concerning mandatory pension funds remained basically the same. Recent proposals tend either to supply the AFP-managed funds with additional capital thanks to increase in mandatory workers' contribution (proposal 'A') or to subsidize benefits paid out by AFP contributory pillar via the rebuilt social security mechanism (proposal 'B'). The latter arrangement, i.e. the social security component, is supposed to draw from increased mandatory workers' contributions as well.

Thus, bringing the state into Chile's pension system back, in spite of the leftist provenience of the change, can be rather viewed as a plan to subsidize total retirement benefits in order to improve the distressing rates of replacement and, in such indirect way, to support the AFP-pillar longevity ${ }^{6}$. However, the alarm-

6 This view corresponds with panorama of social change under democracy in Chile as evaluated by an insider and a sociologist, M.A. Garreton (2012) in his book on improved neo-liberalism and moderate progress. In the period this article refers to the fourth Concertación government (2006-2010) led by socialist Michelle Bachelet initiated major reforms to the social security and pension systems. When in 2009 the political right won the presidency in an electoral process for the first time since 1958 with its candidate Sebastián Piñera, the new government largely maintained the generally business-friendly 
ing performance of mandatory privatized fully-funded pensions in Chile and the radical retreat from this scheme in some follower-countries (Argentina, Peru, Hungary, etc.) offer a lesson that a 'there-is-no-alternative' thinking is not necessarily applicable to pension-system design.

\section{References}

Barr, N. (2001). The truth about pension reform. Finance and Development, $38(3)$.

Barr, N., \& Diamond, P. (2016). Reforming pensions in Chile. Polityka Spoteczna, 1(12).

Bertranou, F. (2016). Pension benefits in Chile: is it possible to improve adequacy and solidarity? Paper presented at the ILO/IZA Conference on 'Assessing the effects of labour market reforms - a global perspective', Geneva, Switzerland.

BTI. (2016). Chile country report. Retrieved 06.02.2017 from http://www. bti-project.org.

Cervera, A. (2014). Chile: pension fund snapshot as of May 2014. Retrieved 06.02.2017 from http://www.credit-suisse.com.

Commission on the Pension System. (2015). Executive summary 2015. Retrieved 10.02.2017 from http://www.comision-pensiones.cl.

Garcia-Huitron, M., \& van Leuvensteijn, M. (2015). International pension reform diffusion: a tale about Chile and the Netherlands trying to learn from each other. Het Verzekerings-Archief, 4.

Garreton, M.A. (2012). Neoliberalismo corregido y progressimo limitado: los gobiernos concertacion en Chile 1990-2010. Santiago: Editorial Arcis.

IMF. (2016). Chile: staff concluding statement of the 2016 article IV mission. Retrieved 06.02.2017 from http://www.imf.org.

Kritzer, B.E. (2008). Chile's next generation pension reform. Social Security Bulletin, 68(2).

Mesa-Lago, C., \& Bertranou, F. (2016). Pension reforms in Chile and social security principles, 1981-2015. International Social Security Review, 69(1). doi:10.1111/issr.12093.

Singh, A. (1996). Pension reform, the stock market, capital formation and economic growth: a critical commentary on the world bank's proposals. International Social Security Review, 49(3). doi:10.1111/j.1468-246x.1996.tb01108.x.

Stowik, P. (2016). Prof. Oręziak: OFE nie są już u nas świętością. Wkrótce Polacy będą dziatać jak Chilijczycy. Retrieved 06.02.2017 from http://serwisy.gazetaprawna.pl.

Vasquez, I. (2016). The attack on Chile's private pension system. Retrieved 06.02.2017 from https://www.cato.org.

policies of the Concertación, and also continued social policies promoted by Bachelet (BTI, 2016). 
Wehlau, D. (2007). Lobbying for pension reform. Institutional investors as driving forces of pension privatization? Paper presented at the 14th workshop on alternative economic policy in Europe, Brussels, Belgium.

Ząbkowicz, A. (2014). Institutional interests and institutional change: Poland on the second wave of pension reforms. Equilibrium. Quarterly Journal of Economics and Economic Policy, 9(3). doi:10.12775/EQUIL.2014.024.

Ząbkowicz, A. (2016). A paradox of reforming pensions in Poland. Equilibrium. Quarterly Journal of Economics and Economic Policy, 11(3). doi:10.12775/ EQUIL.2016.026.

Zorilla, R. (2016). Chile's lower house raises solidarity pensions. Retrieved 06.02.2017 from http://www.bnamericas.com.

\section{Acknowledgements}

Author contributions: author has given an approval to the final version of the article.

Funding: this research was fully funded by the Jagiellonian University in Kraków, Faculty of Management and Social Communication statutory sources.

Note: the results of this study were presented at 9th International Conference on Applied Economics Contemporary Issues in Economy (June 22-23, Torun, Poland). 


\section{Appendix}

Table 1.

Median replacement rates, ten last salaries in 2007-2014

\begin{tabular}{lccc}
\hline \multicolumn{1}{c}{ Specification } & Total & Men & Women \\
\hline without APS (self-financed) & 34 & 48 & 24 \\
with APS (aporte provisional solidario) & 45 & 60 & 31 \\
\hline
\end{tabular}

Source: Own preparation based on Mesa-Lago \& Bertranou (2016, p. 8).

Table 2.

Administrative costs of the private pension system

\begin{tabular}{lcrrr}
\hline & \multicolumn{2}{c}{ Cost (in \% of taxable income) } & \\
\cline { 2 - 3 } Year & Net fee paid to AFP, old-age fee & $\begin{array}{c}\text { Disability and survival premium } \\
\text { to the insurance company }\end{array}$ & Total cost/deposit (in \%)* \\
\hline 1981 & - & - & 24.4 \\
2007 & 1.71 & 0.73 & 24.4 \\
2010 & 1.49 & 1.49 & 29.8 \\
2013 & 1.39 & 1.26 & 26.7 \\
2014 & 1.14 & 2.40 & 24.0 \\
\hline
\end{tabular}

Note:

* The deposit is $10 \%$ of taxable income.

Source: Own preparation based on Mesa-Lago \& Bertranou (2016, p. 9).

Scheme 1 .

Pension benefits under 2008 reform

\begin{tabular}{|c|c|c|c|}
\hline \multicolumn{2}{|c|}{ pillar } & non-contributory & $\begin{array}{l}\text { contributory (only fully funded } \\
\text { capital accounts) }\end{array}$ \\
\hline \multicolumn{2}{|r|}{ administration } & Social Security Administration* & $\begin{array}{l}\text { pension management companies** } \\
\text { and insurance companies }\end{array}$ \\
\hline \multicolumn{2}{|r|}{ financing } & general tax revenues & $\begin{array}{l}\text { workers contributions according } \\
\text { to taxable wage }\end{array}$ \\
\hline \multirow{3}{*}{$\begin{array}{l}\text { bene- } \\
\text { fits }\end{array}$} & $\begin{array}{l}\text { poorest } 60 \% \text {, no contribu- } \\
\text { tions required }\end{array}$ & basic pension benefit, $\mathrm{PBS}^{* * *}$ & - \\
\hline & $\begin{array}{l}\text { poorest } 60 \% \text {, some contri- } \\
\text { butions required }\end{array}$ & $\begin{array}{c}\text { supplementary or additional pension } \\
\text { benefit, APS }\end{array}$ & $\begin{array}{l}\text { ‘self-financed pension benefit', } \\
\text { PCI***** }\end{array}$ \\
\hline & fully contributory & - & 'self-financed pension benefit', PCI \\
\hline
\end{tabular}

Note:

* Instituto de Prevision Social.

** AFPs - adminstradoras de fondos de pensiones.

*** PBS — pension basica solidaria.

**** APS — aporte provisional solidario.

***** PCI - pension autofinanciada; pension benefit derived from individual pension savings.

Source: Own preparation based on Bertranou (2016, p. 14). 
Scheme 2.

Proposed structure for the Chilean pension system, the Advisory Pension Commission (Bravo Commission), proposal 'B'

\begin{tabular}{|c|c|c|c|c|}
\hline \multirow{2}{*}{\multicolumn{2}{|c|}{ pillar }} & \multirow[b]{2}{*}{ non-contributory } & \multicolumn{2}{|c|}{ contributory } \\
\hline & & & social insurance & $\begin{array}{l}\text { fully-funded individual } \\
\text { accounts }\end{array}$ \\
\hline & financing & general tax revenues & $\begin{array}{l}\text { worker and employer } \\
\text { contributions; state con- } \\
\text { tributions from general tax } \\
\text { revenues }\end{array}$ & $\begin{array}{l}\text { worker and employer } \\
\text { contributions }\end{array}$ \\
\hline \multicolumn{2}{|c|}{ administration } & $\begin{array}{l}\text { Social Security Adminis- } \\
\text { tration }\end{array}$ & $\begin{array}{l}\text { Social Security Admin- } \\
\text { istration; social security } \\
\text { fund }\end{array}$ & $\begin{array}{l}\text { Social Security Adminis- } \\
\text { tration; pension manage- } \\
\text { ment companies (AFPs) } \\
\text { and insurance companies }\end{array}$ \\
\hline \multirow{3}{*}{$\begin{array}{l}\text { bene- } \\
\text { fits }\end{array}$} & $\begin{array}{l}\text { no contributions } \\
\text { required }\end{array}$ & PBS & - & - \\
\hline & $\begin{array}{l}\text { workers with } \\
\text { wages up } \\
\text { to the median } \\
\text { earnings distri- } \\
\text { bution* }\end{array}$ & PBS & PSS** & - \\
\hline & $\begin{array}{l}\text { workers with } \\
\text { wages above } \\
\text { the median earn- } \\
\text { ings distribution }\end{array}$ & $\begin{array}{l}\text { PBS (affluence test to ex- } \\
\text { clude richest 20\%) }\end{array}$ & PSS & PCI \\
\hline
\end{tabular}

Note:

* This is 350.000 USD.

** PSS: social insurance benefit.

Source: Bertranou (2016, p. 15). 